\title{
KEJAHATAN AKUNTANSI DALAM KAITANNYA DENGAN UNDANG-UNDANG NOMOR 5 TAHUN 2011 TENTANG AKUNTAN PUBLIK
}

\author{
Herman Fikri Tegoeh \\ Dosen Sekolah Tinggi Ilmu Hukum Sumpah Pemuda \\ E-mail: herman_intann@yahoo.co.id
}

\begin{abstract}
ABSTRAK
Seorang Akuntan Publik mempunyai peran penting terutama dalam peningkatan kualitas dan kredibilitas informasi keuangan atau laporan keuangan suatu entitas. Tugas Akuntan Publik mengemban kepercayaan masyarakat untuk memberikan opini atas laporan keuangan suatu entitas. Dengan demikian, tanggung jawab Akuntan Publik terletak pada opini atau pernyataan pendapatnya atas laporan atau informasi keuangan suatu entitas, sedangkan penyajian laporan atau informasi keuangan tersebut merupakan tanggung jawab manajemen.

Sering terjadinya skandal akuntansi (accounting scandals) adalah skandal politik dan bisnis yang muncul dengan pengungkapan kelakuan buruk para eksekutif perusahaan publik. Kejahatan tersebut biasanya melibatkan metode yang kompleks untuk menyalahgunakan dana atau menyesatkan, melebih-lebihkan pendapatan, mengecilkan biaya, melebih-lebihkan nilai aset perusahaan atau mengurangi pelaporan terhadap besarnya kewajiban, terkadang mereka juga melakukan kerjasama dengan pejabat di perusahaan lain atau afiliasinya. Jika mengacu pada pengertian skandal akuntansi tersebut di atas maka kejahatan akuntansi cenderung lebih dekat dengan istilah fraudulent statement (fraud yang berkenaan dengan penyajian laporan keuangan).
\end{abstract}

Kata Kunci: Accounting Scandals, Kejahatan, Perusahaan, Politik, dan Publik.

\begin{abstract}
A Certified Public Accountant has an important role in improving the quality and credibility of financial information or financial report of an entity. A public accountant has task in carrying out public confidence to provide an opinion on the financial statements of an entity. Thus, the responsibility of A Public Accountant lies on their opinion or statement on financial information of an entity, while the presentment of report or financial information is the managerial responsibility.

Frequently, the accounting scandals are influence by politics and business, which appeared by the disclosure of misdeeds executives of public companies. This crime typically involve complex methods for misusing funds or misleading, exaggerating revenue, reducing cost, overstating the value of corporate assets or reducing the amount of obligations, sometimes they are working with the officials in other companies or affiliates. By referring the meaning of accounting scandals above, accounting crimes tend to be fraudulent statement (fraud whose regarding to the presentation of financial statements).
\end{abstract}

Keywords: Accounting Scandals, Crimes, Companies, Politics, and Public. 


\section{PENDAHULUAN}

Profesi Akuntan Publik sangat erat kaitannya dengan aktivitas bisnis, analisa serta pendapat dari Akuntan Publik terhadap suatu laporan keuangan sebuah perusahaan akan sangat menentukan dasar pertimbangan dan pengambilan keputusan bagi seluruh pihak ataupun publik yang menggunakannya. Para investor dalam mempertimbangkan dan memutuskan kebijakan investasinya, para penasehat keuangan ataupun investasi dalam memberikan arahan pada para investor terhadap keadaan dan prospek dari sebuah perusahaan, para pemberi pinjaman (lenders) dalam mempertimbangkan serta memutuskan langkah pemberian ataupun penghentian pinjaman bagi perusahaan tersebut.

Sewajarnya Perusahaan harus dapat memberikan gambaran yang benar tentang status kesehatan keuangannya, karena berhubungan dengan konsekuensi hukum dari aktivitas berbisnis. Dimana konsekuensi hukum itu mengharuskan masing-masing pihak yang terikat di dalamnya untuk dapat memenuhi setiap kewajiban yang telah disepakati. Kegagalan dalam pemenuhan kewajiban tersebut, baik sebagai akibat dari tindakan wan prestasi.
Sebagaimana diketahui, tidak dapat dipungkiri begitu penting peran Akuntan Publik dalam memberikan informasi yang tepat mengenai laporan keuangan suatu perusahaan sesuai dengan Undang-Undang Nomor 5 tahun 2011 tentang Akuntan Publik. Seorang Akuntan Publik merupakan profesi yang muncul dari adanya tuntutan publik akan adanya mekanisme komunikasi yang independen antara entitas ekonomi dengan para stakeholder terutama yang berkaitan dengan akuntabilitas dari entitas yang bersangkutan. Melihat dari salah satu contoh di atas, hendaknya ada peningkatan standar mutu dari profesionalisme seorang Akuntan Publik. $^{1}$

Undang-Undang Nomor 5 Tahun 2011 tentang Akuntan Publik telah mengatur secara garis besar dan mendefinisikan tentang peran seorang Akuntan Publik di dalam lingkungan masyarakat yang terdiri dari tugas, hak, kewajiban, tanggung jawab, sanksi dan lain sebagainya dari seorang Akuntan Publik maupun Kantor Akuntan Publik yang bertujuan untuk lebih mensosialisasikan kepada masyarakat akan pentingnya penggunaan jasa

1 Tuanakotta, Theodorus M. Akuntansi Forensik dan Audit Investigatif, Edisi 2. Salemba Empat, Jakarta, 2010, Tanpa Halaman. 
akuntan Publik dalam praktiknya di lingkungan masyarakat.

Sering terjadinya skandal akuntansi (accounting scandals) atau skandal akuntansi perusahaan (corporate accounting scandals) adalah skandal politik dan bisnis yang muncul dengan pengungkapan kelakuan buruk para eksekutif perusahaan publik. Kejahatan tersebut biasanya melibatkan metode yang kompleks untuk menyalahgunakan dana atau menyesatkan.

Fraudulent statement atau financial statement fraud itu sendiri didefinisikan berbeda-beda. Association of Certified Fraud Examiners (ACFE) mendefinisikan financial statement fraud sebagai "Salah satu atau pengabaian atas fakta-fakta yang material yang disengaja, atau data akuntansi yang menyesatkan, dan ketika mempertimbangkan dengan semua informasi yang tersedia, akan menyebabkan pembaca laporan mengganti atau mengubah penilaian atau keputusannya." Sedangkan The Treadway Commission mendefinisikan sebagai "melakukan tindakan secara sengaja atau ceroboh, yang merupakan perbuatan atau kelalaian, yang menghasilkan materi laporan keuangan yang menyesatkan". ${ }^{2}$

Definisi di atas, dapat menyimpulkan bahwa definisi financial statement fraud adalah salah satu atau kelalaian yang disengaja, baik itu dari segi jumlah/besaran atau pengungkapan laporan keuangan yang ditujukan untuk menipu pengguna laporan keuangan, khususnya investor dan kreditor, dalam hal ini manajemen melakukan pengolahan laporan keuangan untuk keuntungan mereka sendiri. Namun demikian, dengan membandingkan definisi financial statement fraud tersebut di atas, secara umum kejahatan akuntansi itu sendiri dapat didefinisikan sebagai kejahatan/kecurangan yang dilakukan dalam bidang ekonomi dan berkaitan dengan akuntansi. Hal ini berarti financial statement fraud merupakan salah satu bentuk kejahatan akuntansi.

Berdasarkan latar belakang di atas, maka penulis merumuskan permasalahan sebagai berikut. 1. Bagaimana bentuk kejahatan akuntansi yang manakah yang sering terjadi dilakukan oleh perusahaanperusahaan yang ada di Indonesia?; 2.

2 Kholis, Azizul, I Nengah Rata, Sri Sulistiyowati, dan Endah Prapti Lestari. Kewajiban hukum (legal liability) auditor, Jurnal Bisnis dan Akuntansi, Volume 3, Nomor 3 Desember 2001. Tanpa Halaman. 
Bagaimanakah penerapan dan penanggulangan terhadap kejahatan akuntansi?

\section{PEMBAHASAN}

\section{A. Teori Penegakan Hukum}

Menurut teori penegakan hukum yang dikemukakan oleh Joseph Goldstein bahwa Total Enforcement yaitu dimana ruang lingkup penegakan hukum pidana sebagaimana yang dirumuskan oleh hukum substantif (substantive law of crimes). Berarti penegakan hukum pidana secara total ini tidak mungkin dapat dilakukan, sebab para penegak hukum termasuk Polri dibatasi secara ketat oleh hukum acara pidana: seperti adanya aturan-aturan tentang penangkapan, penahanan, penggeledahan, penyitaan dan pemeriksaan pendahuluan. ${ }^{3}$

Hukum pidana formil Indonesia ditentukan dalam Kitab Undang-Undang Hukum Acara Pidana (KUHAP) yang mengatur bagaimana bekerjanya lembaga-lembaga penegak hukum seperti kepolisian, kejaksaan, pengadilan dan lembaga pemasyarakatan dalam melaksanakan tugasnya. Instansi

3 Satjipto Raharjo, Masalah Penegakan Hukum Suatu Tinjauan Sosiologis, CV. Sinar Baru Bandung, 2005, Tanpa Halaman. penegak hukum itu merupakan satu rangkaian dalam sistem peradilan pidana.

Di dalam KUHAP menjelaskan bahwa penahanan hanya dapat dilakukan kepada tersangka atau terdakwa yang telah melakukan tindak pidana atau percobaan maupun memberikan bantuan dalam tindak pidana tersebut dalam hal tindak pidana itu diancam dengan pidana penjara lima tahun atau lebih. ${ }^{4}$

Tindak pidana sebagaimana dimaksud dalam Undang-Undang Nomor 5 Tahun 2011 tentang Akuntan Publik, yang diputuskan DPR RI pada tanggal 5 April 2011 dan disahkan presiden tanggal 3 Mei 2011 dengan ancaman pidana maksimal 5 tahun penjara dan denda Rp300.000.000,00 (tiga ratus juta rupiah), dan undangundang tersebut mengatur tentang regulasi profesi, asosiasi profesi, perizinan, hak dan kewajiban, tanggung jawab, sanksi, dan lain-lain. Undangundang tersebut lebih lengkap membahas tentang akuntan publik lebih lengkap dibandingkan undang-undang sebelumnya yaitu Undang-Undang Nomor 34 Tahun 1954 tentang

4 Soesilo, Kitab Undang-Undang Hukum Pidana (KUHP) Serta Komentar-Komentarnya Lengkap Pasal Demi Pasal, Politeia, Bogor, 1993, Tanpa Halaman. 
Pemakaian Gelar Akuntan. Dalam menciptakan kehidupan masyarakat yang harmonis dan teratur, maka dalam kehidupan bermasyarakat diperlukan suatu sistem hukum.

Sistem hukum yang dikemukakan oleh Harokl J Berman adalah keseluruhan aturan prosedur spesifik, yang karena itu dapat dibedakan ciricirinya dari kaidah-kaidah sosial yang lain pada umumnya dan struktur otoritas yang professional guna mengontrol proses-proses sosial yang terjadi dalam masyarakat. $^{5}$

Hukum akan berperan baik bila ketiga komponen dimaksud, yaitu struktur hukum, substansi hukum dan budaya hukum itu saling berinteraksi dan memainkan peranan sesuai dengan fungsinya, sehingga hukum akan berjalan efektif sesuai dengan fungsinya, sehingga hukum akan berjalan efektif sesuai dengan fungsinya. Seandainya apabila ketiga komponen sistem hukum tersebut tidak berfungsi dengan baik, maka akan muncul permasalahan dalam upaya untuk memfungsikan hukum

5 Soetand Wignyosubroto, Dari Hukum Kolonial ke Hukum Nasional Dinamika Sosial Politik Dalam Perkembangan Hukum di Indonesia, PT Raja Grafindo Persada, Jakarta, 1995, hlm. 1. sebagai sarana pembaharuan dan pembangunan masyarakat itu sendiri. ${ }^{6}$

Berkenaan dengan substansi ketiga di atas erat kaitannya dengan hukum acara pidana. Kehadiran hukum acara pidana menjadi penting karena ia menjadi panduan bagi aparat penegak hukum dan masyarakat untuk mencegah jangan sampai terjadi masyarakat main hakim sendiri. ${ }^{?}$

\section{B. Teori Pertanggungjawaban Pidana}

Untuk dapat mempersalahkan seorang melakukan pelanggaran pidana bukan merupakan hal yang mudah, demikian pula terhadap penjatuhan sanksinya. Dalam hukum pidana konsep liability atau pertanggungjawaban pidana merupakan konsep sentral yang dikenal dengan ajaran kesalahan, dalam bahasa Latin ajaran kesalahan ini dikenal dengan sebutan mens rea, doktrin mens rea tersebut didasarkan pada maxim actuc non fatit reum nisi mens sit rea, yang berarti suatu perbuatan tidak mengakibatkan seseorang bersalah kecuali ada pikiran orang itu jahat. Berdasarkan asas tersebut ada dua syarat

6 Mochtar Kusumaatmadja, Konsep-konsep Hukum Dalam Pembangunan (Kumpulan Karya Tulis), Alumni, Bandung, 2002, hlm. 3.

7 Bambang Purnomo, Orientasi Hukum Acara Pidana Indonesia, Amarta, Yogyakarta, 1988, hlm. 2. 
yang harus dipenuhi untuk dapat memidana seseorang yaitu ada perbuatan lahiriah yang terlarang (actus reus) dan sikap batin jahat/ tercela (mens rea), sikap batin dapat berupa kesengajaan dan kealpaan. ${ }^{8}$

Menurut Roeslan Saleh, kesalahan itu merupakan syarat subjektif dan mutlak bagi pertanggungjawaban pidana. Dengan kata lain manakala pelaku melakukan perbuatan tercela, dia tentunya tidak dipidana bila tidak mempunyai kesalahan, sebagaimana tercantum pada asas tidak tertulis yang berbunyi geen straft zonder schuld. ${ }^{9}$

Muladi memberikan patokanpatokan karakteristik yang harus diperhatikan dalam membuat kebijakan hukum pidana yang akan datang, yaitu: 1) Hukum pidana nasional mendatang yang dibentuk harus memenuhi pertimbangan sosiologis, politis, praktis, dan juga dalam kerangka ideologis Indonesia; 2) Hukum pidana nasional mendatang tidak boleh mengabaikan aspek-aspek yang bertalian dengan kondisi manusia, alam, dan tradisi Indonesia; 3) Hukum pidana nasional mendatang harus dapat menyesuaikan diri dengan kecenderungan-kecende- rungan universal yang tumbuh di dalam pergaulan masyarakat beradab; 4) Sistem peradilan pidana, politik criminal, dan politik penegakan hukum merupakan bagian dari politik sosial, maka hukum pidana nasional mendatang harus memperhatikan aspek-aspek yang bersifat preventif; dan 5) Hukum pidana nasional mendatang harus selalu tanggap terhadap perkembangan ilmu pengetahuan dan teknologi guna meningkatkan efektifitas fungsinya di dalam masyarakat. ${ }^{10}$

Muladi telah mengemukakan di atas, sebenarnya merupakan internalisasi atau implementasi nilai-nilai Pancasila dalam pembaharuan hukum pidana. Sebagaimana diketahui, usaha-usaha pembaharuan hukum pidana, baik materiil maupun formil, terus dilakukan. Dalam konteks pembaharuan hukum pidana materiil, telah beberapa kali dibentuk Tim Pembaharuan KUHP Nasional yang sudah mulai bekerja pada tahun 60-an hingga sekarang, dan sudah menghasilkan Konsep RUU KUHP, bahkan sekarang sudah menjadi RUU KUHP yang siap dibahas di Dewan Perwakilan Rakyat untuk mendapatkan persetujuannya.

10 Idem. 
Dalam pembaharuan hukum pidana melalui jalur peraturan perundang-undangan di luar KUHP, yang berjumlah puluhan, bahkan mungkin telah ratusan undang-undang, baik yang merupakan undang-undang (di bidang) hukum pidana, maupun undangundang (pidana) di bidang administrasi (administrative penal law).

Upaya penegakan hukum memberikan arti adanya upaya untuk menjaga agar keberadaan hukum yang diakui di dalam suatu masyarakat dapat tetap ditegakkan. Upaya tersebut pada dasarnya harus menjamin agar setiap warga negara mematuhi hukum yang berlaku di dalam masyarakat yang bersangkutan.

Penegakan hukum bukanlah merupakan suatu kegiatan yang berdiri sendiri, melainkan mempunyai hubungan timbal balik yang erat dengan masyarakatnya. Oleh karena itu dalam membicarakan masalah ini sebaiknya tidak mengabaikan pembicaraan mengenai struktur masyarakat yang ada di belakangnya. Penegakan hukum dalam suatu masyarakat mempunyai kecenderungan sendiri yang disebabkan oleh struktur masyarakatnya. ${ }^{11}$

11 Romli Atmasasmita, Pengantar Hukum Kejahatan Bisnis (Business Crime), Kencana, Bogor, 2003. Tanpa Halaman.
Struktur masyarakat ini memberikan pengaruh, baik berupa penyediaan sarana sosial yang memungkinkan penegakan hukum itu dijalankan, maupun memberikan hambatan-hambatan yang menyebabkan ia tidak dapat dijalankan atau kurang dapat dijalankan secara optimal. Jadi masalah pokok dalam penegakan hukum sebenarnya terletak pada faktor-faktor yang mungkin mempengaruhinya.

\section{Etika Profesi Auditor}

Etika profesi sangat diperlukan dalam profesi seorang auditor. Adapun peranan etika dalam profesi auditor adalah sebagai berikut: 1) Audit membutuhkan pengabdian yang besar pada masyarakat dan komitmen moral yang tinggi; 2) Masyarakat menuntut untuk memperoleh jasa para auditor publik dengan standar kualitas yang tinggi, dan menuntut mereka untuk bersedia mengorbankan diri. Itulah sebabnya profesi auditor menetapkan standar teknis dan standar etika yang harus dijadikan panduan oleh para auditor dalam melaksanakan audit; 3) Standar etika diperlukan bagi profesi audit karena auditor memiliki posisi sebagai orang kepercayaan dan menghadapi kemungkinan benturan- 
benturan kepentingan; dan 4) Kode etik atau aturan etika profesi audit menyediakan panduan bagi para auditor profesional dalam mempertahankan diri dari godaan dan dalam mengambil keputusan-keputusan sulit. ${ }^{12}$

Etika sudah menjadi kebutuhan setiap orang dalam menjalankan aktivitas mereka. Etika merupakan serangkaian prinsip atau nilai moral yang dimiliki oleh setiap orang, termasuk etika dalam menjalankan profesi. Salah satu profesi yang mempunyai etika adalah akuntan publik.

Prinsip etika akuntan atau kode etik akuntan itu sendiri meliputi delapan butir pernyataan. Kedelapan butir pernyataan tersebut merupakan hal-hal yang seharusnya dimiliki oleh seorang akuntan. Delapan butir tersebut adalah, Tanggung Jawab Profesi; Kepentingan Publik; Integritas; Objektivitas; Kompetensi dan Kehati-hatian Profesional; Kerahasiaan; Perilaku Profesional; serta Standar Teknis. ${ }^{13}$

Penjelasan aturan etika merupakan penjabaran lebih lanjut dari prinsipprinsip etika dan ditetapkan untuk masing-masing kompartemen. Untuk akuntan sektor publik, aturan etika

12 Kholis, Azizul, ... Op Cit.

13 Tuanakotta, Theodorus M. Akuntansi ... Op Cit. ditetapkan oleh IAI Kompartemen Akuntan Sektor Publik (IAI-KASP). Sampai saat ini, aturan etika ini masih dalam bentuk exposure draft, yang penyusunannya mengacu pada Standard of Professional Practice on Ethics yang diterbitkan oleh the International Federation of Accountants (IFAC) $)^{14}$.

Berdasarkan aturan etika ini, seorang profesional akuntan sektor publik harus memiliki karakteristik yang mencakup: 1) Penguasaan keahlian intelektual yang diperoleh melalui pendidikan dan pelatihan; 2) Kesediaan melakukan tugas untuk masyarakat secara luas ditempat instansi kerja maupun untuk auditan; 3) Berpandangan obyektif; dan 4) Penyediaan layanan dengan standar pelaksanaan tugas dan kinerja yang tinggi. ${ }^{15}$

Penerapan aturan etika ini dilakukan untuk mendukung tercapainya tujuan profesi akuntan yaitu: 1) Bekerja dengan standar profesi yang tinggi, 2) Mencapai tingkat kinerja yang diharapkan, dan, 3) Mencapai tingkat kinerja yang memenuhi persyaratan kepentingan masyarakat.

14 Ibid.

15 Toruan, L Henry, Tanggung Jawab Akuntan Publik, Media Akuntansi, No.18/ Juni/2001, Penerbit Intama Artha Indonusa, Jakarta. 2001. Tanpa Halaman. 


\section{Kewajiban Hukum Auditor}

Apabila terjadinya pelanggaran yang dilakukan oleh seorang Akuntan Publik dalam memberikan jasanya, baik atas temuan-temuan bukti pelanggaran apapun yang bersifat pelanggaran ringan hingga yang bersifat pelanggaran berat, berdasarkan PMK No. 17/PMK.01/2008 hanya dikenakan sanksi administratif, berupa: sanksi peringatan, sanksi pembekuan ijin dan sanksi pencabutan ijin ${ }^{16}$.

Hukuman dalam pemberian sanksi hingga pencabutan izin baru dilakukan dalam hal seorang Akuntan Publik tersebut telah melanggar ketentuanketentuan yang diatur dalam SPAP dan termasuk juga pelanggaran kode etik yang ditetapkan oleh IAPI, serta juga melakukan pelanggaran peraturan perundang-undangan yang berlaku yang berhubungan dengan bidang jasa yang diberikan, atau juga akibat dari pelanggaran yang terus dilakukan walaupun telah mendapatkan sanksi pembekuan izin sebelumnya, ataupun tindakan-tindakan yang menentang langkah pemeriksaan sehubungan dengan adanya dugaan pelanggaran profesionalisme akuntan publik.

16 Ibid.
Namun hukuman yang bersifat administratif tersebut walaupun diakui merupakan suatu hukuman yang cukup berat bagi eksistensi dan masa depan dari seorang Akuntan Publik, ternyata masih belum menjawab penyelesaian permasalahan ataupun resiko kerugian yang telah diderita oleh anggota masyarakat, sebagai akibat dari penggunaan hasil audit dari Akuntan Publik tersebut.

Lebih jauh Soedarjono dalam Sarsiti mengungkapkan bahwa auditor memiliki beberapa tanggung jawab yaitu: 1) Tanggung jawab terhadap opini yang diberikan; 2) Tanggung jawab terhadap profesi; 3) Tanggung jawab terhadap klien; 4) Tanggung jawab untuk mengungkapkan kecurangan; 5) Tanggung jawab terhadap pihak ketiga; dan 6) Tanggung jawab terhadap pihak ketiga atas kecurangan yang tidak ditemukan. ${ }^{17}$

Banyak profesional akuntansi dan hukum percaya bahwa penyebab utama tuntutan hukum terhadap kantor akuntan publik adalah kurangnya pemahaman pemakai laporan keuangan tentang perbedaan antara kegagalan bisnis dan

17 Sarsiti, Kualitas audit dan tanggung jawab auditor terhadap penuntutan kerugian, Jurnal Keuangan dan Bisnis, Volume 1, Nomor 2 Oktober 2003. 
kegagalan audit, dan antara kegagalan audit serta risiko audit. Menurut Loebbecke dan Arens Kegagalan dibagi menjadi 3 yaitu berikut kegagalan bisnis, kegagalan audit dan risiko audit. ${ }^{18}$

Dalam melaksanakan audit, akuntan publik telah gagal mematuhi standar profesinya, maka besar kemungkinannya bahwa business failure juga dibarengi oleh audit failure. Dalam hal yang terakhir ini, akuntan publik harus bertanggung jawab. Sementara, dalam menjalankan tugasnya, akuntan publik tidak luput dari kesalahan. Kegagalan audit yang dilakukan dapat dikelompokkan menjadi ordinary negligence, gross negligence, dan fraud. ${ }^{19}$

Ordinary negligence merupakan kesalahan yang dilakukan akuntan publik, ketika menjalankan tugas audit, dia tidak mengikuti pikiran sehat (reasonable care). Dengan kata lain setelah mematuhi standar yang berlaku ada kalanya auditor menghadapi situasi yang belum diatur standar. Dalam hal ini auditor harus menggunakan "common sense" dan mengambil keputusan yang

18 Saleh, AS Rachmad dan Saiful Anuar Syahdan, Perspektif kewajiban hukum terhadap advokasi akuntan public di Indonesia, artikel, Media Akuntansi, No.35/September-Oktober/2003, Penerbit Intama Artha Indonusa, Jakarta. 2003.

19 Ibid. sama seperti seorang (typical) akuntan publik bertindak. $^{20}$

Gross negligence merupakan kegagalan akuntan publik mematuhi standar profesional dan standar etika. Standar ini minimal yang harus dipenuhi. Bila akuntan publik gagal mematuhi standar minimal (gross negligence) dan pikiran sehat dalam situasi tertentu (ordinary negligence), yang dilakukan dengan sengaja demi motif tertentu maka akuntan publik dianggap telah melakukan fraud yang mengakibatkan akuntan publik dapat dituntut baik secara perdata maupun pidana. $^{21}$

Sebagian besar profesional akuntan setuju bahwa bila suatu audit gagal mengungkapkan kesalahan yang material dan oleh karenanya dikeluarkan jenis pendapat yang salah, maka kantor akuntan publik yang bersangkutan harus diminta mempertahankan kualitas auditnya. Jika auditor gagal menggunakan keahliannya dalam pelaksanaan auditnya, berarti terjadi kegagalan audit, dan kantor akuntan publik tersebut atau perusahaan asuransinya harus membayar kepada mereka yang menderita kerugian akibat kelalaian auditor tersebut.

20 Ibid

21 Tuanakotta, Theodorus M. Akuntansi Forensik ... Op Cit. 
Pemahaman terhadap hukum Auditor akan terkena sanksi atas tidaklah mudah mengingat pemahaman tersebut menuntut suatu kesadaran dari perilaku-perilaku yang terlibat di dalamnya dan juga adanya kemungkinan interpretasi yang berbeda-beda terhadap keberadaan suatu hukum. Hal ini juga yang terjadi pada profesi akuntan publik dimana perilaku-perilaku yang terlibat terkadang kurang memahami secara benar apa yang telah menjadi kewajiban yang nantinya akan mempunyai konsekuensi terhadap hukum. Suatu pemahaman yang baik terhadap hukum akan membawa profesi akuntan publik minimal ke dalam praktik yang sehat, yang dapat meningkatkan performance dan kredibilitas publik yang lebih baik.

Apabila akuntan publik kurang memahaminya pada iklim keterbukaan di era reformasi seperti sekarang ini maka akan dapat membawa perkembangan fenomena ke dalam konteks yang lebih luas pada publik yang sudah mulai berani melakukan tuntutan hukum terhadap berbagai profesi termasuk profesi akuntan publik.

\section{E. Kewajiban Hukum Bagi Auditor}

Secara umum Auditor sama dengan profesi lainnya merupakan subjek hukum dan peraturan lainnya.

kelalaiannya, seperti kegagalan untuk mematuhi standar profesional di dalam kinerjanya. Profesi ini sangat rentan terhadap penuntutan perkara atas kelalaiannya yang digambarkan sebagai sebuah krisis.

Kewajiban hukum yang mengatur akuntan publik di Indonesia secara eksplisit memang belum ada, akan tetapi secara implisit hal tersebut sudah ada seperti tertuang dalam Standar Profesional Akuntan Publik (SPAP), Standar Akuntansi Keuangan (SAK), Peraturan-Peraturan mengenai Pasar Modal atau Bapepam, UU Perpajakan dan lain sebagainya yang berkenaan dengan kewajiban hukum akuntan.

Perangkat hukum yang mengatur akuntan publik di Indonesia sangat dibutuhkan oleh masyarakat termasuk kalangan profesi untuk melengkapi aturan main yang sudah ada. Hal ini dibutuhkan agar di satu sisi kalangan profesi dapat menjalankan tanggung jawab profesionalnya dengan tingkat kepatuhan yang tinggi, dan di sisi lain masyarakat akan mempunyai landasan yang kuat bila sewaktu-waktu akan melakukan penuntutan tanggung jawab profesional terhadap akuntan publik. 
Dengan uraian-uraian di atas, dapat disimpulkan bahwa kewajiban hukum bagi seorang akuntan publik adalah bertanggung jawab atas setiap aspek tugasnya sehingga jika memang terjadi kesalahan yang diakibatkan oleh kelalaian pihak auditor, maka akuntan publik dapat dimintai pertanggungjawaban secara hukum sebagai bentuk kewajiban hukum auditor. Akuntansi forensik muncul karena pesatnya perkembangan fraud yang terjadi, untuk mengungkapkan fraud tersebut diperlukan ilmu mengenai akuntansi forensik. Istilah akuntansi forensik merupakan terjemahan dari forensic accounting.

Definisi akuntansi forensik menurut Hopwood et al yaitu "forensic accounting is the application of investigative and analytical skills for the purpose of resolving financial issues in a manner that meets standards required by courts of law". ${ }^{22}$

Dengan terjemahan sebagai berikut, akuntansi forensik adalah aplikasi keterampilan investigasi dan analitik yang bertujuan untuk menyelesaikan masalah-masalah keuangan melalui cara-cara yang sesuai dengan standar yang ditetapkan oleh pengadilan dan hukum.

22 Rezaee, Z., Financial Statement Fraud, Prevention and Detection. New York, John Wiley \& Sons, Inc. 2002.
Menurut Tuanakotta akuntansi forensik ialah "penerapan disiplin akuntansi dalam arti luas, termasuk auditing, pada masalah hukum untuk penyelesaian hukum di dalam atau di luar pengadilan"23.

Dari beberapa pengertian akuntansi forensik di atas, dapat disimpulkan bahwa akuntansi forensik adalah penerapan disiplin akuntansi yang berdasarkan pada keterampilanketerampilan dalam menginvestasi dan menganalisis yang bertujuan untuk menyelesaikan masalah keuangan yang dilakukan berdasarkan peraturanperaturan yang ditetapkan oleh hukum.

\section{F. Pengertian Fraud}

Istilah Fraud atau yang sering dikenal dengan istilah kecurangan merupakan hal yang sekarang banyak dibicarakan di Indonesia. Pengertian fraud itu sendiri merupakan penipuan yang sengaja dilakukan, yang menimbulkan kerugian pihak lain dan memberikan keuntungan bagi pelaku kecurangan dan atau kelompoknya. Fraud sebagai representasi tentang fakta material yang palsu dan sengaja atau ceroboh sehingga diyakini dan ditindak-

23 Tuanakotta, Theodorus M. Akuntansi Forensik ... Op Cit. 
lanjuti oleh korban dan kerusakan korban. Dalam bahasa aslinya fraud meliputi berbagai tindakan melawan hukum. ${ }^{24}$

Amrizal mendefinisikan kecurangan "Fraud is criminal deception intended to financially benefit the deceiver" yaitu kecurangan adalah penipuan kriminal yang bermaksud untuk memberi manfaat keuangan kepada si penipu ${ }^{25}$.

Adapun menurut the Association of Certified Fraud Examiners (ACFE), fraud adalah: Perbuatan-perbuatan yang melawan hukum yang dilakukan dengan sengaja untuk tujuan tertentu (manipulasi atau memberikan laporan keliru terhadap pihak lain) dilakukan orang-orang dari da-lam atau luar organisasi untuk mendapatkan keuntungan pribadi ataupun kelompok secara langsung atau tidak langsung merugikan pihak lain. ${ }^{26}$

Jadi istilah fraud adalah mencakup segala macam yang dapat dipikirkan manusia, dan yang diupayakan oleh seseorang untuk mendapatkan keuntungan dari orang lain, dengan saran yang salah atau pemaksaan kebenaran,

24 Rezaee, Z., Financial Statement Fraud: Prevention .... Op Cit.

25 Amrizal, CFE, Pencegahan dan Pendeteksian Kecurangan oleh Internal Auditor, Jakarta. 2004.

26 Ibid. dan mencakup semua cara yang tidak terduga, penuh siasat atau tersembunyi, dan setiap cara yang tidak wajar yang menyebabkan orang lain tertipu atau menderita kerugian.

\section{G. Kejahatan Akuntansi dan Bentuk Sanksi Hukum terhadap Akuntan Publik}

Pada dasarnya kejahatan akuntansi bermuara pada pelaporan keuangan yang menyesatkan bagi penggunanya, termasuk aktivitas yang tidak benar atau ilegal pada proses pengidentifikasian dan pengukuran transaksi-transaksi keuangan. Adapun beberapa bentuk kejahatan akuntansi, diantaranya adalah: 1) Manajemen Laba yang Tidak Sah (illegal earnings management); 2) Pendapat (opini) Auditor Eksternal yang Tidak Benar; 3) Kejahatan Perbankan; 4) Kejahatan Akuntansi di Pasar Modal; dan 5) Transaksi dengan pihak yang memiliki hubungan istimewa (RelatedParty Transactions). ${ }^{27}$

\footnotetext{
2 Romli Atmasasmita, Pengantar Hukum Kejahatan Bisnis (Bisnis Crime). Bogor: Kencana. 2003.
} 


\section{H.Penggolongan Kejahatan}

\section{Akuntansi Dalam Kriminologi}

Kejahatan akuntansi atau skandal akuntansi melibatkan kaum elit bisnis dan kaum profesional. Contoh kasus yang populer adalah kasus Enron dimana harga saham perusahaan tersebut anjlok karena ulah pendiri Enron, mantan $C E O$, eksekutif Enron lainnya serta Kantor Akuntan Publik Arthur Anderson yang bersekongkol memanipulasi laporan keuangan Enron. Kejahatan akuntansi di perbankan dan di pasar modal juga melibatkan kaum profesional.

Dengan melihat pelakunya maka disimpulkan bahwa kejahatan akuntansi ini masuk dalam kategori kejahatan kerah putih (white collar crime) adalah kejahatan yang dilakukan oleh orangorang terhormat dan status sosial tinggi dalam kaitannya dengan okupasinya.

Dalam kaitannya dengan hukum positif yang berlaku di Indonesia, Kitab Undang-Undang Hukum Pidana (KUHP) dan Undang-Undang yang terkait menyebutkan beberapa pasal yang terkait dengan kejahatan akuntansi, diantaranya adalah: 1) Berkaitan dengan manajemen laba ilegal, dapat dikenakan Pasal 390 KUHP; 2) Berkaitan dengan pemberian opini auditor yang menyesatkan, dapat dikenakan Pasal 416 KUHP; 3) Berkaitan dengan kejahatan perbankan yang merupakan kategori penggelapan, dapat dikenakan Pasal 372 KUHP; 4) Berkaitan dengan kejahatan perbankan sehubungan pemalsuan rekening nasabah, dapat dikenakan Pasal 49 ayat (1) huruf c UU Perbankan No. 10 Tahun 1998; dan 5) Berkaitan dengan kejahatan akuntansi di pasar modal yang berupa manipulasi pasar, dapat dikenakan pasal 91 Undang-Undang Nomor 8 tahun 1995 tentang Pasar Modal. $^{28}$

Untuk mengetahui penyebab terjadinya kejahatan akuntansi dapat menggunakan konsep segitiga fraud. Konsep segitiga fraud ini dicetuskan oleh Donald R. Cressey untuk menjelaskan tiga faktor penyebab yang muncul dalam setiap situasi fraud. Ketiga faktor tersebut adalah motif, rasionalisasi, dan kesempatan ${ }^{29}$.

Motif menggambarkan suatu dorongan kebutuhan atas dana atau alasan seseorang yang menyebabkan dia

28 Adami Chazawi, Pelajaran Hukum Pidana Bagian 2: Penafsiran Hukum Pidana, Dasar Peniadaan, Peberatan \& Peringanan Pidana, Kejahatan Aduan, Perbarengan \& Ajaran Kausalitas, PT. Raja Grafindo Persada, Jakarta, 2002.

29 Weygandt, J.J., P.D. Kimmel, dan D.E. Kieso, Accounting Principles, 10th Edition. Hoboken, New Jersey: John Wiley \& Sons, Inc. 2012. 
perlu untuk melakukan suatu kejahatan. Unsur ini kadang-kadang disebut sebagai tekanan, yang biasanya merupakan suatu bentuk pendorong untuk memperoleh penghasilan tambahan yang akan digunakan untuk berbagai tujuan.

Pelaku fraud menggambarkan tindakan mereka sebagai suatu tindakan yang bukan kategori kejahatan, melainkan hanya mengambil suatu keuntungan akibat ketidakadilan yang dilakukan oleh perusahaan atau orang lain. Mereka memaklumi tindakan mereka tersebut dan mengatasi kekhawatiran dengan beranggapan bahwa tindakan mereka bukan suatu pelanggaran hukum. Pelaku fraud merasionalisasi tindakan mereka. Rasionalisasi inilah yang memungkinkan mereka untuk melakukan kegiatan fraud.

Karena kejahatan akuntansi biasanya dilakukan oleh tim manajemen tingkat atas berarti kejahatan ini sering terjadi dalam lingkungan perusahaan yang corporate governance nya tidak dapat dipertanggungjawabkan dan tidak berjalan efektif. Pada dasarnya manajemen akan lebih enggan untuk terlibat dalam kejahatan akuntansi jika mekanisme corporate governance tersebut berjalan efektif dan meningkatkan mekanisme pencegahan dan deteksi kemungkinan adanya kejahatan akuntansi.

Dalam hal terjadinya pelanggaran yang dilakukan oleh seorang Akuntan Publik dalam memberikan jasanya, baik atas temuan-temuan bukti pelanggaran apapun yang bersifat pelanggaran ringan hingga yang bersifat pelanggaran berat, berdasarkan PMK No. 17/PMK.01/2008 hanya dikenakan sanksi administratif berupa: sanksi peringatan, sanksi pembekuan ijin dan sanksi pencabutan ijin. ${ }^{30}$

Sedangkan menurut UndangUndang Nomor 5 Tahun 2011 Tentang Akuntan Publik yang diatur dalam Pasal 55 dan 56. Penghukuman dalam pemberian sanksi hingga pencabutan izin baru dilakukan dalam hal seorang Akuntan Publik telah melanggar ketentuan yang diatur pula dalam SPAP dan termasuk juga pelanggaran kode etik yang ditetapkan oleh IAPI, serta melakukan pelanggaran peraturan perundang-undangan yang berlaku atau juga akibat dari pelanggaran yang terus dilakukan walaupun telah mendapatkan sanksi pembekuan izin sebelumnya, ataupun tindakan-tindakan yang

30 Toruan, L Henry, Tanggung Jawab Akuntan Publik, Media Akuntansi, No. 18/ Juni/2001, Penerbit Intama Artha Indonusa, Jakarta. 2001. 
menentang langkah pemeriksaan sehubungan dengan adanya dugaan pelanggaran profesionalisme akuntan publik.

Sanksi administratif menurut Undang-Undang nomor 5 Tahun 2011 Tentang Akuntan Publik yang diatur dalam Pasal 53 dapat pula dikenakan kepada akuntan publik yang melanggar aturan yang sudah ditetapkan oleh undang-undang.

Berdasarkan uraian di atas jelas sikap professional dari sang Akuntan Publik timbul bukan karena rangkaian ancaman hukuman administratif, perdata dan bahkan pidana yang dapat menjeratnya dalam hal terjadinya pelanggaran, akan tetapi lebih karena tuntutan profesi akuntan publik membutuhkan suatu proses perjalanan yang sehat dan transparan, sehingga dalam hal menyajikan suatu keberadaan suatu perusahaan melalui laporan keuangannya tersebut, publik sangat membutuhkan akuntan publik yang benar-benar mempunyai kemampuan yang baik, professional dan independen dalam menjamin maksimumnya tingkat akurasi kebenaran dari hasil pernyataan pendapatnya terhadap Laporan Keuangan.

\section{Penanggulangan Kejahatan}

\section{Akuntansi}

Praktik akuntansi forensik tumbuh dengan pesat tidak lama setelah krisis ekonomi melanda Indonesia tahun 1997. Tingkat korupsi yang masih tinggi juga menjadi pendorong yang kuat untuk berkembangnya praktik akuntansi forensik di Indonesia. Istilah akuntansi forensik lebih tepat digunakan jika sudah bersinggungan dengan bidang hukum. Sementara hasil audit investigatif dapat, tetapi tidak harus, digunakan dalam proses pengadilan atau bentuk penyelesaian hukum lainnya. Namun dalam penerapannya akuntansi forensik memang banyak bersinggungan dengan hukum.

Teknik audit yang biasa diterapkan dalam audit umum seperti pemeriksaan fisik, konfirmasi, memeriksa dokumen, review analitikal, meminta penjelasan tertulis atau lisan kepada auditan, menghitung kembali dan mengamati pada dasarnya dapat digunakan untuk audit investigatif. Hanya dalam audit investigatif, teknik-teknik audit tersebut dilakukan secara eksploratif, mencari wilayah garapan, ataupun pendalaman.

Selain teknik audit yang biasa digunakan dalam audit umum, ada beberapa teknik audit investigatif yang 
bisa diterapkan apabila tidak ditemukan bukti dokumen. Net worth method dan expenditure method adalah teknik audit untuk menelusuri ketidakwajaran penghasilan dan atau pola konsumsi pelaku tindak pidana. Teknik lain adalah dengan menelusuri aliran uang (follow the money) yang selama ini dilakukan oleh PPATK. Meski hampir selalu bersinggungan dengan hukum, bukan berarti akuntansi forensik ini melulu atas permintaan aparat penegak hukum. Pada dasarnya siapapun bisa meminta digelarnya audit forensik, mulai dari masalah perceraian, konflik premi asuransi, gugatan perdata, hingga penilaian terhadap kinerja perusahaan.

\section{J. Akuntan Forensik}

Profesi akuntan forensik sangat dibutuhkan oleh penegak hukum, yakni jika ada sebuah transaksi yang dicurigai, maka abdi hukum bisa meminta bantuan akuntan forensik untuk menjelaskan dari mana dan ke mana transaksi tersebut mengalir. Akuntan forensik menerapkan keterampilan khusus di bidang akuntansi, audit, keuangan, metode kuantitatif, beberapa bidang hukum, penelitian dan keterampilan dalam menginvestigasi untuk mengumpulkan, menganalisis, dan mengevaluasi bukti dan untuk menginterpretasikan dan mengkomunikasikan temuan.

Seorang akuntan forensik menyelidiki kasus fraud yang sudah diketahui atau dicurigai harus dapat mengembangkan teori kasus tersebut dan menggabungkannya ke dalam metode ilmiah. Pendekatan ini mencakup identifikasi masalah (hipotesis), mengumpulkan bukti dan data, menganalisis data untuk menguji hipotesis, dan menarik kesimpulan. Dalam melakukan penyelidikan.

Di sektor publik (pemerintahan), praktik akuntan forensik serupa dengan apa yang digambarkan di atas, bahwa tahap-tahap dalam seluruh rangkaian akuntansi forensik terbagi-bagi diantara berbagai lembaga. Ada lembaga yang melakukan pemeriksaan keuangan negara, ada beberapa lembaga yang merupakan bagian dari internal pemerintahan, ada lembaga-lembaga pengadilan, ada lembaga yang menunjang kegiatan memerangi kejahatan pada umumnya, dan korupsi khususnya seperti (PPATK), dan lembaga-lembaga lainnya seperti KPK. Juga ada lembaga swadaya masyarakat yang berfungsi sebagai pressure group.

Masing-masing lembaga tersebut mempunyai mandat dan wewenang yang 
diatur dalam konstitusi, undang-undang atau ketentuan lainnya. Mandat dan wewenang ini akan mewarnai lingkup akuntansi forensik yang diterapkan. Di samping itu keadaan politik dan macammacam kondisi lain akan mempengaruhi lingkup akuntansi forensik yang diterapkan, termasuk pendekatan hukum atau nonhukum. Dampak yang terjadi di sektor pemerintahan apabila terdapat fraud adalah terganggunya pelaksanaan penyelenggaraan negara. Apabila tidak ditunjang dengan penegakan bidang hukum yang kuat, standar akuntansi dan lain-lain maka tingkat korupsi dan kelemahan dalam penyelenggaraan negara akan meningkat.

Berdasar uraian di atas maka akuntan forensik sangat dibutuhkan dalam mengungkap kejahatan akuntansi yang berakibat banyaknya terjadi pelanggaran hukum baik pihak swasta maupun pemerintah dalam bentuk manipulasi data keuangan berupa tindak pidana korupsi yang berakibat kerugian negara yang tidak sedikit dan menyengsarakan rakyat.

\section{PENUTUP}

\section{A. Kesimpulan}

1. Kejahatan akuntansi merupakan kejahatan atau kecurangan yang dilakukan dalam bidang ekonomi dan berkaitan dengan akuntansi. Kejahatan akuntansi dilakukan oleh manajemen puncak suatu organisasi dengan cara memanipulasi transaksi dan/atau laporan keuangan. Kejahatan akuntansi dapat dikategorikan sebagai kejahatan kerah putih.

2. Kejahatan akuntansi tidak terlihat secara nyata dan korban seringkali tidak merasakan adanya kejahatan ini. Ketika kejahatan ini terdeteksi dan terjadi maka dampak yang ditimbulkannya sangat besar yaitu perusahaan/organisasi dan negara akan mengalami kebangkrutan dan perekonomian negara bahkan dunia akan mengalami goncangan.

3. Akuntansi forensik merupakan formulasi yang dapat dikembangkan sebagai strategi preventif, detektif dan persuasif melalui penerapan prosedur audit forensik dan audit investigatif yang bersifat litigation suport untuk menghasilkan temuan dan bukti yang dapat membantu proses pengambilan putusan di pengadilan. Di samping itu dengan fraud examination yang tidak terlepas dari akuntansi forensik akan menjadi bahan untuk profesi akuntansi khususnya untuk menelusuri adanya kemungkinan- 
kemungkinan kecurangan yang lagi terhadap kejahatan akuntansi dan

dilakukan.

menindak tegas setiap kejahatan

tersebut.

B. Saran

2. Peran Akuntansi forensik perlu

1. Proses penegakan hukum terhadap pelaku kejahatan akuntansi belum maksimal mengingat dampak yang ditimbulkannya sangat luar biasa bahkan dapat menggoyahkan ditingkatkan karena merupakan sebuah formulasi yang dapat mengungkap dan membuktikan kejahatan akuntansi di Indonesia. perekonomian negara. Untuk itu para penegak hukum perlu lebih waspada 


\section{DAFTAR PUSTAKA}

\section{A. Buku}

Adami Chazawi, Pelajaran Hukum Pidana Bagian 2: Penafsiran Hukum Pidana, Dasar Peniadaan, Peberatan \& Peringanan Pidana, Kejahatan Aduan, Perbarengan \& Ajaran Kausalitas, PT. Raja Grafindo Persada, Jakarta, 2002.

Amrizal, CFE, Pencegahan dan Pendeteksian Kecurangan oleh Internal Auditor, Jakarta. 2004.

Romli Atmasasmita, Pengantar Hukum Kejahatan Bisnis (Business Crime), Kencana, Bogor, 2003.

Bambang Purnomo, Orientasi Hukum Acara Pidana Indonesia, Amarta, Yogyakarta, 1988.

Mochtar Kusumaatmadja, Konsepkonsep Hukum Dalam Pembangunan (Kumpulan Karya Tulis), Alumni, Bandung, 2002.

Rezaee, Z., Financial Statement Fraud, Prevention and Detection. New York, John Wiley \& Sons, Inc. 2002.

Satjipto Raharjo, Masalah Penegakan Hukum Suatu Tinjauan Sosiologis, CV. Sinar Baru Bandung, 2005.

Soesilo, Kitab Undang-Undang Hukum Pidana (KUHP) Serta KomentarKomentarnya Lengkap Pasal Demi Pasal, Politeia, Bogor, 1993,.

Soetand Wignyosubroto, Dari Hukum Kolonial ke Hukum Nasional Dinamika Sosial Politik Dalam
Perkembangan Hukum di Indonesia, PT Raja Grafindo Persada, Jakarta, 1995.

Tuanakotta, Theodorus M. Akuntansi Forensik dan Audit Investigatif, Edisi 2. Salemba Empat, Jakarta, 2010.

Weygandt, J.J., P.D. Kimmel, dan D.E. Kieso, Accounting Principles, 10th Edition. Hoboken, New Jersey: John Wiley \& Sons, Inc. 2012.

\section{B. Peraturan Perundang-undangan}

Undang-Undang Nomor 1 Tahun 1946 Tentang Aturan Hukum Pidana.

Undang-Undang Nomor 8 Tahun 1981 Tentang Undang-Undang Hukum Acara Pidana.

Undang-Undang Nomor 34 Tahun 1954 tentang Pemakaian Gelar Akuntan;

Undang-Undang Nomor 8 tahun 1995 tentang Pasar Modal;

Undang-Undang Nomor 10 Tahun 1998 tentang Perbankan;

Undang-Undang Nomor 5 Tahun 2011 Tentang Akuntan Publik

\section{Jurnal, Artikel, Makalah, Majalah, Koran, Internet, dan Lain-lain.}

Kholis, Azizul, I Nengah Rata, Sri Sulistiyowati, dan Endah Prapti Lestari. Kewajiban hukum (legal liability) auditor, Jurnal Bisnis dan 
Akuntansi, Volume 3, Nomor 3 Desember 2001.

Toruan, L Henry, Tanggung Jawab Akuntan Publik, Media Akuntansi, No.18/ Juni/2001, Penerbit Intama Artha Indonusa, Jakarta. 2001.

Sarsiti, Kualitas Audit Dan Tanggung Jawab Auditor Terhadap

Artha Indonusa, Jakarta. 2003.
Penuntutan Kerugian, Jurnal Keuangan dan Bisnis, Volume 1, Nomor 2 Oktober 2003.

Saleh, AS Rachmad dan Saiful Anuar Syahdan, Perspektif kewajiban hukum terhadap advokasi akuntan public di Indonesia, artikel, Media Akuntansi, No. 35/SeptemberOktober/2003, Penerbit Intama 